\title{
University Students' Emotional State and Academic Performance: New Insights of Managing Complex Cognitive
}

\author{
Ika Febrilia ${ }^{1}$, Ari Warokka ${ }^{2}$ and Haim Hilman Abdullah ${ }^{2}$ \\ ${ }^{1}$ Citibank Indonesia, Jakarta, Indonesia \\ ${ }^{2}$ College of Business - UUM, Sintok, Malaysia
}

\begin{abstract}
A potentially important but relatively unexplored factor in explaining human capital accumulation during college is mental state (health) problems. Recent empirical findings reveal the impact of mental state, i.e. positive mood, on the performance of the students in processing information. This kind of mental state facilitates cognitive process that leads to better learning performance and satisfaction. Positive mood facilitates complex cognitive functions requiring flexibility, integration, and utilization of cognitive material such as memory, categorization, creative problem solving, decision-making and learning. Little empirical research on students' emotions and their effect on learning and academic performance is available that could guide the design of learning environments. This study extends the literature that has been done mostly in western societies by proposing a further linkage between positive and negative mood to students' learning and the impact of that learning on student's academic performance in Indonesian universities, which is rarely investigated in non-western societies. The data were collected by using questionnaires and a sample of 106 students who have mid-term examination (assessment) in their active academic semester. The result, based on analysis using structural equation modeling, indicates that the tested model has an acceptable fit. The findings also indicate that (1) positive mood has no influence on learning, (2) negative mood has negative influence on learning, and (3) learning has positive influence on student's academic performance.
\end{abstract}

Keyword: Mental State, Positive Mood, Negative Mood, Learning, Academic Performance

\section{Introduction}

One of the primary concerns in younger populations is that mental state problems may affect human capital accumulation-in particular, the amount and productivity of schooling-which may in turn have lifelong consequences for employment, income, and other outcomes. Understanding the link between mental state and academic success is therefore, a crucial step towards assessing the returns to preventing, detecting and treating mental health issues among young people. In the modern economy, college education has become an increasingly important component of human capital, and has been associated with substantially higher earnings (Jaeger and Page, 1996; Kane and Rouse, 1995). In psychology, mental state is one's current state of mind under the domains of appearance, attitude, behavior, mood, and effect, speech, thought process, thought content, perception, cognition, insight, and judgment (Trzepacz, and Baker, 1993).

Copyright (C) 2011 Ika Febrilia, Ari Warokka and Haim Hilman Abdullah. This is an open access article distributed under the Creative Commons Attribution License unported 3.0, which permits unrestricted use, distribution, and reproduction in any medium, provided that original work is properly cited. Contact author: Ari Warokka. E-mail: ari.warokka@uum.edu.my 
Positive and negative mood, emotions, and effects, which are known as personality characteristics and traits, have generated many researchers' interests because of the influence of its relationships on job commitment, job satisfaction, absenteeism, turnover, group affective tone, and job success within an organization (Chavez and Mendez, 2008). More recently, some empirical findings have tied these personality characteristics and traits to leadership effectiveness through emotional intelligence (EI). These findings assert that EI can help leaders solve complex problems, make better decisions, be more adaptable, and handle the crisis in a more emotionally stable manner (Goleman, 1995; Mayer and Salovey, 1995; Goleman et al., 2002; Tsai, Chen, and Cheng, 2009). In other words, this level of attention indicates that those personality characteristics and traits are significant aspects of organizational life and at a certain level, are worthy to see this relationship in education or teaching area.

In any education institution, learning process is a main concern and focus of many parties who are involved in it. Learning is a loop in which the teacher facilitates learning. Students perform what they have learned, the teacher assesses students' performance and provides student feedback on the students' performance, and students use the feedback to improve their performance on the next learning task (Lasso, 2008). Learning also means one's ability in processing various information that he/she receives. Bryan, Mathur, and Sullivan (1996) find that the impact of positive mood on the performance of the students in processing information. Positive mood facilitates complex cognitive functions requiring flexibility, integration, and utilization of cognitive material such as memory, categorization, creative problem solving, decision-making and learning. Therefore, it is reasonable to assume that it also affects the underlying cognitive organization (Isen, 1987). In general, in studies of the impact of mood, positive mood has shown a facilitating impact on memory, learning, and behavior, whereas the negative effect has a depressing impact. Positive mood has also been found to enhance the performance of behaviors that lead to positive outcomes such as greater personal power and greater freedom to act as one wish.

\section{Research Question}

Isen (1984) argues that mood indirectly influences an on-going and succeeding event, although it does not have real nature effect and does not change the basic activity or context of that carry-on event. In other words, when a student is in a certain learning process, such as studying the material, concentrating on certain topics, understanding the lectures, memorizing and remembering some jargons or terminologies, and analyzing an experiment result, he/she will be influenced by his/her on-going mood. As a result, one's performance is also affected by what he/she feels.

In higher education context, each student will generate academic performance that is variable for each other, whether it is determined by individual characteristic (for example, owned IQ) or by other factors, such as student's self-motivation to study. When mood (positive and negative) takes place in individual's mental state, intuitively, it will interfere in his/her studying process, therefore academic performance as a result of one's learning process will also be disrupted. Student will perceive difficult in understanding the material transferred by its instructor, be less enthusiastic, eventually, generate adverted study behavior, and at the final point, perform an un-optimal academic performance. Therefore, in this study, we develop a structural equation model to measure the effect of positive and negative mood on academic performance, which is mediated by learning process.

\section{Literature Review}

A mood is defined as "a type of affective state which is transient and particular to a specific time and situation" (Jeon, 1990, p.24). Moods 
can influence cognitive processes such as perception and memory (Parkinson, Totterdell, Briner and Reynolds, 1996). Their research has indicated that if we feel good then we see the world around us in a positive way. It is believed that we process moodcongruent information more easily (that is, material that has an emotional tone consistent with the current mood state). Good (positive) moods influence us to pick out (and possibly exaggerate) the positive aspects of the environment. In other words, positive mood is one's mental state and feelings where she/he feels more confident, optimistic, and unconstrained (Forest, Clark, Mills, and Isen, 1979). Individuals with positive moods were likely to process information less systematically, but more creatively and flexibly than those with negative moods (Park, 2002), therefore, if they feel good about the target object, they render a positive evaluation (Schwarz, 2001). It can be said that when being in a bad mood, we may be more likely to focus on the negative aspects of our environment and evaluate them in the least positive ways.

Therefore, when one feels anxiety, depression, and fatigue, it can be said that negative mood takes place in his/her feeling state (Watson and Tellegen, 1985).

In many empirical studies, positive mood has been explored as a facilitating factor of changing people's other affective experience such as attitude, motivation, creativity, and problem solving skills. These findings are consistent with the facilitation hypothesis of emotions that positive mood helps long-term memory and retrieval and facilitates the working memory process (Erez and Isen, 2002; Isen and Patrick, 1983; Petty, Schumann, Richman, and Strathman, 1993, Weiss, Nicholas, and Daus, 1999). The series of studies by Isen and her colleagues have suggested that positive mood improves creative problem solving by altering the cognitive context in which cognitive activity takes place and by giving cues of an extensive and varied set of materials (Isen and Daubman, 1984; Isen, Daubman, and
Nowicki, 1987; Isen, Jhonson, Mertz, and Robinson; 1985; Isen, Rogenzweig, and Young, 1991).

Positive mood has also been studied as a direct or indirect factor in changing people's other affective experiences such as attitude, judgment, evaluation and satisfaction (Isen, Shalker, Clark, and Karp, 1978; Isen and Patrick, 1983; Petty et al., 1993; Weiss et al., 1999). Overall, people who are in a positive emotional state make more positivejudgments and give favorable feedback because they interpret situations more positively than they would at other times. The studies of Erez and Isen (2002) and Isen and Reeve (2005) also indicated that positive emotions facilitate intrinsic motivation by influencing the cognitive process involved in motivation.

Negative moods are proposed to derive from discrepancies between personal standards and perceived current status (Carver and Scheier, 1990; Martin and Tesser, 1996; Wicklund, 1979). People in a negative mood feel further from the standard and may analyze the situation carefully, attending to specific details in order to reduce this discrepancy (Cervone, Kopp, Schaumann, and Scott, 1994). When people perform objectively difficult tasks, perceived goal attainability influences the functional impact of negative mood on effort. Those in a negative mood either mobilize little effort because they perceive task demands to be too high, or increase effort because negative mood acts as a warning signal that attainment of achievable goals is threatened (Cervone et al., 1994; Gendolla and Krusken, 2002).

Prior empirical studies have demonstrated that different negative moods have different effects on performance (Hanin, 2000; Lane and Terry, 2000; Schwarz and Bless, 1991; Schwarz, 2001). Anxiety has been shown to be associated with good performance in some studies and poor performance in others, whereas depression is consistently associated with poor performance. Lane and 
Terry (2000) proposed that individuals in a depressed mood tend to direct feelings of anger internally, leading to suppression, selfblame and, ultimately, performance decrements (Spielberger, 1991). At least four reasons have been offered for why a negative mood is associated with a reduction in cognitive performance, all of them focusing on the reduction of information processing capacity. The resource allocation model (Ellis and Ashbrook, 1988) points out that people in a sad mood are concerned with extra-task processing (e.g., thinking about their own bad mood) or with task-irrelevant processing. Oaksford et al. (1996) argue for depletion of central executive processes, whereas Bohner, Bless, Schwarz, and Strack (1988) suggest a capacity reduction, since subjects in a bad mood are more concerned with finding out why they are in this specific mood. Last, Isen $(1984,1987)$ proposed that a person in a negative mood tries to regain a better mood ("mood repair"). Consequently, the focus of cognitive capacity is both on the task and on mood correction.

Learning process happens when one is acquiring new knowledge, behaviors, skills, values, or preferences and may involve synthesizing different types of information (Magno, 2003). Peterson and Piaget (1996) explained learning as a process that takes place through assimilation, accommodation, and equilibration. It starts from absorbing new experiences from the environment and adding these to the previous experiences, integrating the new experiences with the old, and formatting new insights and ways of thinking as a result of this integration. After assimilation and accommodation occur, the individual is now in a state of equilibrium where the information processed becomes part of his or her schema (Reyes, 2000).

Magno (2003) argued that each learner is responsible for his or her own learning and therefore the rate of learning for each individual varies. The factors that contribute to individual differences in performance as an output of learning depend on these categories, firstly, lasting and general characteristics of the individual (e.g. there are individuals who can easily comprehend instructions). Secondly, lasting but specific characteristics of the individual (e.g. some possess knowledge and skills specific to a particular form of evaluation), and thirdly, temporary but general characteristics of the individual (e.g. this includes health, fatigue, motivation, and emotional strain).

The aim of learning is to acquire new skills and new knowledge on the basis of a repeated personal experience (Bower and Hilgard, 1981). However, both everyday educational and clinical experience and research indicate that strong negative emotions such as anxiety and fear of examinations (Pekrun and Jerusalem, 1996) or depression (Baker \& Shannon, 1995; Brown, Scott, Bench, and Dolan, 1994) can have potent adverse effects on cognitive processing and can impair learning performance as well as performance on transfer tasks. Nevertheless, what about the impact of mood on cognitive processes? It is quite obvious that students are continuously learning and acquiring cognitive skills in various moods and that it is impossible not to learn while being in this diffuse background state of mind. Therefore, it is important to know more about potential effects of mood in learning settings.

Academic performance is measured by the increasing of examination and assignment results' efficiency, effectiveness, and quality, as an evaluation or assessment method on student's performance. This performance can be achieved, if it is supported by qualified education system and effective learning process (Lebcir, Wells, and Bond, 2008; Lasso, 2008). Related to the moods, improved performance has been observed in subjects in a positive mood when a task requires either elaboration of the given data (Abele, Gendolla, and Petzold, 1998), decision-making (Isen and Labroo, 2003), logical thinking (Abele, 1995), problem solving (Isen, Rosenzweig, and Young, 1991), or broadening the scope of attention (Fredrickson and Branigan, 2005). 
Furthermore, Estrada, Isen, and Young (1997) showed that people in a positive mood were more likely to adhere to data that did not fit with a preconceived idea that they were entertaining. In addition, an increased flexibility in thinking has been found to cooccur with positive mood (Greene and Noice, 1988; Isen et al., 1987): subjects in a positive mood solved insight problems (Duncker, 1945) or word association problems (Mednick, Mednick, and Mednick, 1964) faster and more accurately than subjects in a negative mood.

In sum, the empirical findings are controversial; a positive mood can be associated with reduced cognitive performance but also with more flexible thinking; meanwhile, a negative mood can result in more systematic and data-oriented information processing but can also impair performance.

\section{Framework of the Study}

Previous empirical findings find that positive mood states increase memory on various tasks, mastery of a discrimination task, and altruism (Jones and George, 1998). In 1996, Bryan et. al. found that positive mood also facilitates complex cognitive functions that require flexibility, integration, and utilization of cognitive material (e.g., word association and memory, creativity, and problemsolving). Their study also finds that positive moods induce students to organize the academic material in memory for better recall. It supports that student's positive mood will provide excitement to him/her to study; as a result, they are able to perform a better academic performance. It can be said that the higher the level of one's positive mood, the higher one's eagerness and motivation to study and get a better or the higher the examination result. Therefore, based on those arguments, the first hypothesis is:

\section{$\mathrm{H}_{1}$ : Positive Moods Have Positive Influence on Learning}

One's negative moods sometime have certain ability in processing information more systematically, although at the same time, with less creativity (Ciancy and Bierstaker, 2009). Negative moods, for example, have also been found to produce low-effort processing of information, the use of less complex semantic processing strategies (Ellis, Thomas, and Rodriguez, 1984), and lower cognitive processing effort (Leight and Ellis, 1981). Brand, Reimer, and Opwis (2007) find that one's negative mood will deteriorate learning process; therefore, it would produce adverted academic performance. It can be stated that the higher level of negative moods, the higher possibility of one gets lazy and not being motivated to study, as a result, he/she will get an un-optimal academic performance. Therefore, based on those arguments, the second hypothesis is:

\section{$\mathrm{H}_{2}$ : Negative Moods Have Negative Influence on Learning}

Besides individual characteristics, such as IQ, mood or feeling states have influenced thestudent's learning process (Magno, 2003). A good learning process is assumed to produce a better academic performance (Lebcir, Wells, and Bond, 2008). One study that supports this argument is the study of Lan and Li (2003), which suggests an alternative learning process as an effort to improve student academic performance. It is argued that the better the student's learning process, the better the academic performance that is able to be produced, and vice versa. Therefore, based on those arguments, the third hypothesis is:

\section{$\mathrm{H}_{3}$ : Learning Process Has a Positive Influence on Student's Academic Performance}

All these hypotheses can be summarized in the followed figure: 


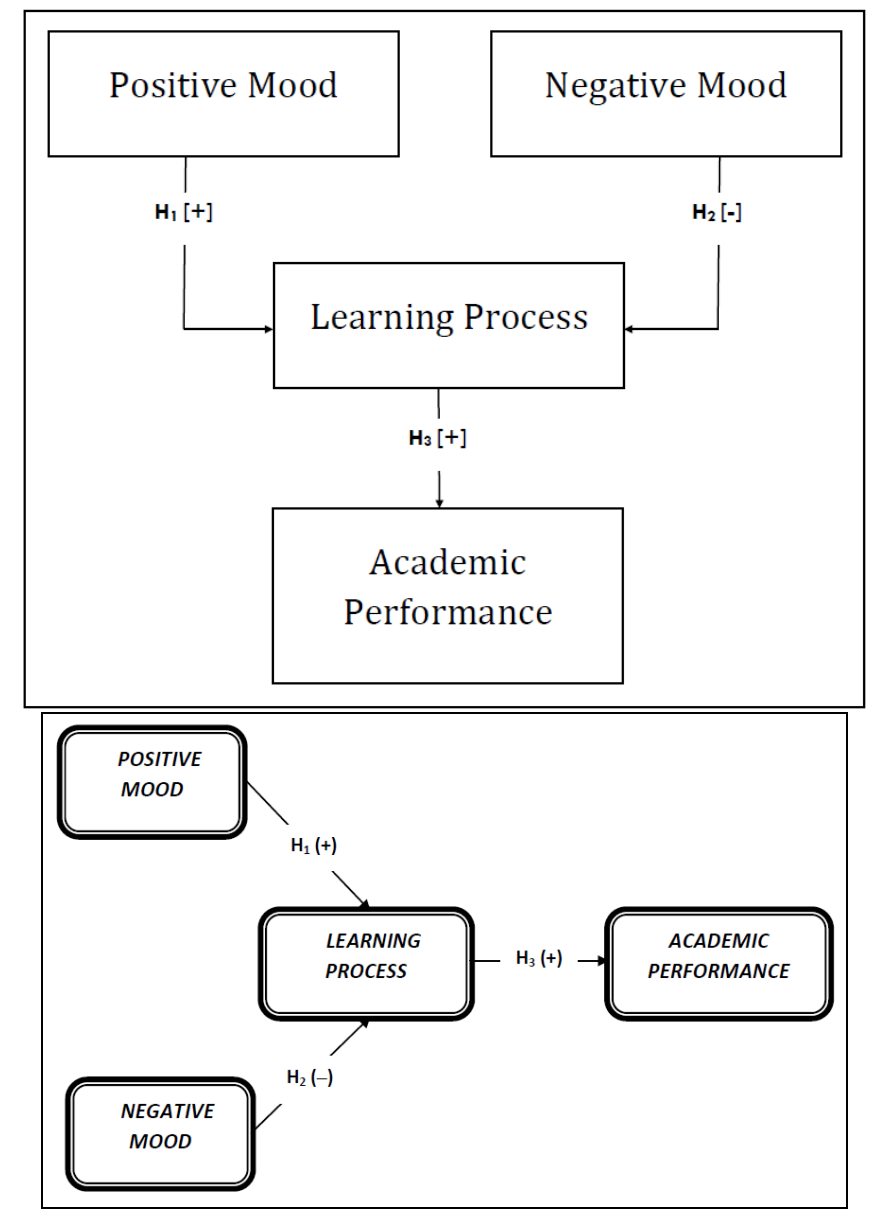

Fig. 1: Research Model of the University Students' Emotional State and Academic Performance

\section{Research Methodology}

Respondents were Indonesian private universities students, who were asked to answer the questionnaire a week before taking a midterm examination in order to minimize the possible disturbing situation that was able to affect their mood or feeling states. This was done to determine if mood (positive or negative) would affect the students' learning process in an exam. Then, authors would analyze whether the students' learning process could affect the outcome or the exam results, which was considered as the proxy of academic performance.
In this study, positive mood and negative mood are independent variables. There are six items used to measure each positive mood and negative mood, respectively, in 5Likert scale (5: strongly agree, 4: agree, 3: neutral, 2: disagree, and 1: strongly disagree). There are also six items used to measure learning process which measure self-reported students' learning process, in 5Likert scale (5: always, 4: often, 3: seldom, 2: rarely, and 1: never), such as student's presence rate, assignment submission, reading pre-presence, self-practice lecture materials at home, discussing lecture material with friends, and consulting with 
lecturer before and after the class. Meanwhile, to measure the academic performance, the midterm examination result is used.
The authors distributed 116 questionnaires and there were 106 usable-questionnaires or $86 \%$ response rate. The descriptive statistic reveals results as follows:

Table 1: Inter-correlations

\begin{tabular}{lcccccc}
\hline Constructs & Mean & Std. Dev. & $(1)$ & $(2)$ & $(3)$ & $(4)$ \\
\hline (1) Positive Mood & 4.05 & 0.565 & 1 & - & - & - \\
(2) Negative Mood & 2.03 & 0.622 & $-0.390^{* *}$ & 1 & - & - \\
(3) Learning & 3.72 & 0.739 & $0.200^{*}$ & -0.177 & 1 & - \\
(4) Academic Performance & 65.51 & 14.072 & 0.124 & -0.188 & $0.230^{*}$ & 1 \\
\hline
\end{tabular}

Note: ${ }^{* *} \mathrm{p}<0.01{ }^{*} \mathrm{p}<0.05$

The independent variables' correlation, i.e., positive mood and negative mood, reveals that there is no severed multicollinearity, because the value $(-0.390)$ is still below the maximum value, i.e., 0.80 , which indicates the existence of multicollineartiy (Gujarati, 1995). The significant and positive correlation between positive mood and learning reveals that students' positive mood will influence his/her readiness to face the examination through various learning processes. Meanwhile, students' welllearning process will proceed to good examination results, as proved by the positive and significant correlation between learning process and academic performance.

The next step is to measure the validity and reliability of all items in the proposed constructs by using AMOS 16. From this process, there are two invalid items in learning construct. The validity and reliability test reveals that only two items of the learning process construct are not reliable, i.e., LearnProc1 and LearnProc2, which have Cronbach's Alpha value and factor loading below the minimum value 0.60 (Gujarati, 1995). Meanwhile, to test the construct validity, it used three approaches of convergent validity, i.e., factor loading, composite reliability, and average variance extracted. Standardized loading estimates should be 0.5 or higher, and ideally 0.7 or higher. In this study, all valid constructs have factor loading more than 0.5. Average variance extracted (AVE) estimates for two factors also should be greater than the square of the correlation between the two factors to provide evidence of discriminate validity. AVE should be 0.5 or more to suggest adequate convergent validity, and in this study, all valid constructs have AVE value more than 0.5. Meanwhile for composite reliability, the construct reliability should be 0.7 or higher to indicate adequate convergence or internal consistency, and in this study, all valid constructs have composite reliability value more than 0.7 . Therefore, it can be said that all constructs used in this study are valid and reliable. 
Table 2: Result of CFA for Measurement Model of the University Students' Emotional State Academic Performance

\begin{tabular}{|c|c|c|c|c|c|}
\hline Construct & Item & $\begin{array}{l}\text { Internal reliability } \\
\text { Cronbach alpha }\end{array}$ & $\begin{array}{l}\text { Factor } \\
\text { loading }\end{array}$ & $\begin{array}{l}\text { Composite } \\
\text { reliability }\end{array}$ & $\begin{array}{l}\text { Average } \\
\text { variance } \\
\text { extracted }\end{array}$ \\
\hline Positive & & & 0.795 & & \\
\hline \multirow[t]{6}{*}{ Mood } & PosMd $_{1}$ & 0.844 & & 0.898 & 0.596 \\
\hline & $\operatorname{PosMd}_{2}$ & & 0.820 & & \\
\hline & $\mathrm{PosMd}_{3}$ & & 0.811 & & \\
\hline & $\mathrm{PosMd}_{4}$ & & 0.747 & & \\
\hline & PosMd $_{5}$ & & 0.653 & & \\
\hline & PosMd $_{6}$ & & 0.795 & & \\
\hline Negative & & & 0.615 & & \\
\hline \multirow[t]{6}{*}{ Mood } & $\mathrm{NegMd}_{1}$ & 0.825 & & 0.864 & 0.516 \\
\hline & $\mathrm{NegMd}_{2}$ & & 0.761 & & \\
\hline & $\mathrm{NegMd}_{3}$ & & 0.645 & & \\
\hline & $\mathrm{NegMd}_{4}$ & & 0.764 & & \\
\hline & $\mathrm{NegMd}_{5}$ & & 0.783 & & \\
\hline & $\mathrm{NegMd}_{6}$ & & 0.725 & & \\
\hline Learning & & & 0.765 & & \\
\hline \multirow[t]{4}{*}{ Process } & LearnProc $_{3}$ & 0.759 & & 0.851 & 0.589 \\
\hline & LearnProc $_{4}$ & & 0.822 & & \\
\hline & LearnProc $_{5}$ & & 0.822 & & \\
\hline & LearnProc $_{6}$ & & 0.649 & & \\
\hline
\end{tabular}

Table 3: Fit Indices for the Measurement Model of the University Students' Emotional State and Academic Performance

\begin{tabular}{lccl}
\hline Fit Index & This Study & Recommended values & \multicolumn{1}{c}{ Source } \\
\hline $\mathrm{df}$ & 2 & & \\
$\chi^{2}$ & 2.003 & & \\
$\chi^{2} / \mathrm{df}$ & 1.001 & $\geq 3.00$ & Gefen (2000) \\
GFI & 0.991 & $\geq 0.90$ & Hoyle (1995) \\
AGFI & 0.953 & $\geq 0.90$ & Chau \& Hu (2001) \\
CFI & 1.000 & $\leq 0.08$ & Bagozzi \& Yi (1988) \\
RMSEA & 0.004 & $\geq 0.90$ & Browne and Cudeck \\
NNFI (TLI) & 1.000 & & Bagozzi \& Yi (1988) \\
\hline
\end{tabular}

The measurement model indices reveal that the proposed model is fit and parsimony. Thus, all variables can be measured in the proposed model. The results can be viewed in Figure 2. 


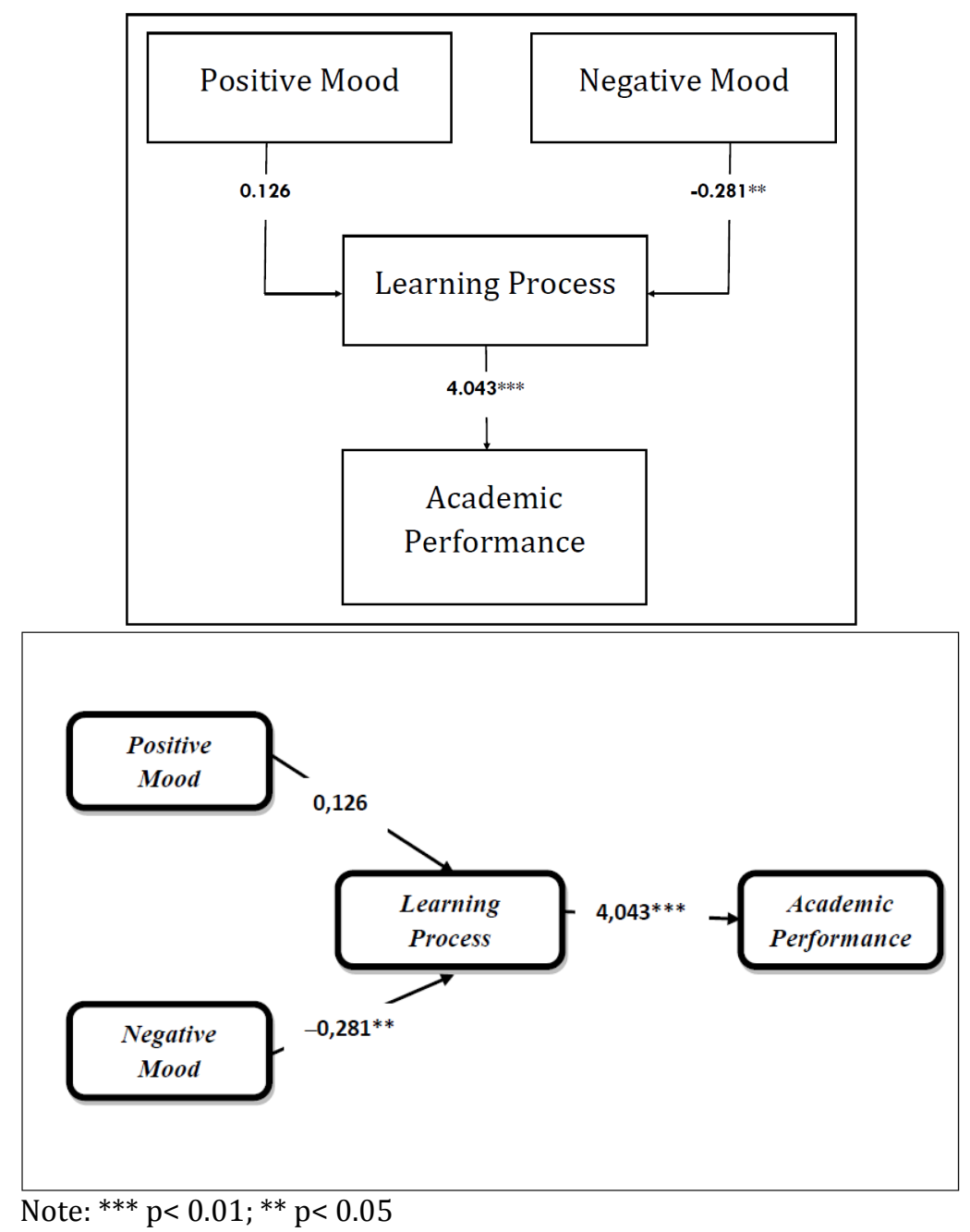

Fig. 2: Path Coefficients and Hypothesis Testing of the University Students' Emotional State and Academic Performance

\section{Findings and Discussion}

In this study, the results of the hypothesis testing do not support the influence of positive mood on learning $(\beta=0,126$; $p>$ 0.1 ). This research is contrary to the first hypothesis stating the positive effect of positive mood on learning. Logically, positive mood can trigger someone (student) to become more excited and motivated to be involved in the learning process, to prepare himself/ herself, and to deal with the academic performance evaluation. However, for a student who is experiencing a good or positive mood, it does not ensure that the student is able to concentrate and be really prepared in the learning process to prepare themselves for exams.

For the second hypothesis testing, the result reveals that negative mood affects learning ( $\beta=-0.281, p<0.05)$. In other words, this study supports the hypothesis that bad mood negatively affects learning. Students with Bad-moods will have a lower level of concentration and perseverance in the learning process to prepare themselves for exams. 
Finally, the result shows that the learning process has big effect on academic performance $(\beta=4.043, p<0.01)$, as indicated in its coefficient value that is more than 1.00 and compared to the coefficients of negative mood and positive mood, which is less than 1.00. It indicates that besides students' mood (positive or negative), there are some independent variables which implicitly play important roles in the learning process. Those variables, unfortunately, are not investigated yet in this study, such as learning environment, type of tasks, and learning feedback. However, this study supports the third hypothesis that learning has positive influence on students' academic performance. This supports the assumption that students, who really run the learning process well, will also get favorable results or good test scores.

\section{Discussion}

A different expected result of the first hypothesis testing provokes some arguments. It can be argued that this happens because students feel that learning is not something that is important, and they tend to focus on feelings or activities that make their mood good. It can be assumed that students are too keen to enjoy their feeling of joy, so they do not concentrate and they feel lazy to do other activities, except those who are able to foster their positive mood. They chose to do an activity that is considered more fun than learning or preparing for exams. Learning will be something boring and less fun for the students who are experiencing the positive mood.

In the second hypothesis testing, students who are in a bad mood tend to be lazy to do various activities, especially activities associated with academic matters. Negative mood will trigger more bad energy to students and they will be less concentrating with no focus on the materials given by the instructor during his presence in the classroom. Students feel very sad and they just think about the factors that make their mood bad, so the learning process will be disrupted. They pay less attention to learning and they prefer the other things outside of class.

Finally, in the third hypothesis testing, the result supports the assumption that students, who actually run the various learning activities well, will also get good test scores. If a student has a strong desire to learn, his/her academic performance will also increase, and vice versa. In other words, students who are eager and diligent in learning process and who do the exercises before the exam, and who are also enthusiastic in discussing the material that is considered difficult with their friends and teachers, will have an increasing academic performance.

\section{Conclusion}

The study has supported previous empirical findings in a certain degree. The positive and insignificant effect of positive mood on learning process has lent a good indication for further research to explore this phenomenon. Meanwhile, the negative and significant effect of negative mood on learning process has provided supporting findings of negative mood effect generalization. Finally, the positive and significant effect of learning process on academic performance indicates that some theories of effective learning process that have been proposed previously in many empirical studies are proved in context of Indonesia higher education environment.

With the positive findings in this study, there are some suggested applicable practices that can be implemented in daily lecturing activities, such as lecturer as; a facilitator is expected to build a conductive classroom situation or a pleasant atmosphere for his/her students. It is expected that lecturers take a significant role to help improve the positive mood of students which might be bad, keep the student away from bad mood, and encourage his/her students' mind to put full concentration only on a good learning process, in order to produce an optimal 
academic performance. It is good for lecturers to be referred to the work of Ramsden (1992), which has constructed the six key principles of effective teaching in higher education, i.e. interest and explanation, concern and respect for student and student learning, appropriate assessment and feedback, clear goals and intellectual challenge, independence, control, and active engagement, and learning from students. These principles implicitly support the creation of supportive and conductive climate for students' positive mood bythe teaching methods, lecturer enthusiasm and commitment, and the pace and level at which learning process is done.

On the other side, students must also try to control their mood. Students should be able to motivate themselves to the relentless will and the high spirit of learning. If these students are able to maintain high motivation in learning, which are supported by the teachers and education institutions, it could be expected to minimize the negative influence of mood on learning and academic performance. In certain cases, probably positive mood could be annoying, such as over-excitement, while in many cases, a negative mood would surely deconstruct the students' learning process.

\section{References}

Abele, A. (1995). 'Stimmung und Leistung,' [Mood and performance]. Gottingen: Hogrefe.

Abele, A., Gendolla, G. H. E., \& Petzold, P. (1998). "Positive Mood and In-Group-OutGroup Differentiation in a Minimal Group Setting," Personality and Social Psychology Bulletin, 24, 1343-1357.

Antony, J., Leung, K., Knowles, G. \& Gosh, S. (2002). "Critical Success Factors of TQM Implementation in Hong Kong Industries," International Journal of Quality and Reliability Management, Vol. 19 (5), 551-566.

Baker, J. E. \& Channon, S. (1995). "The Reasoning in Depression: Impairment on a
Concept Discrimination Learning Task," Cognition and Emotion, 9(6), 579-597.

Bohner, G., Bless, H., Schwarz, N. \& Strack, F. (1988). "When do Events Trigger Attributions? The Impact of Valence and Subjective Probability," European Journal of Social Psychology, 18, 335-345.

Bower, G. H. \& Hilgard, E. R. (1981). "Theories of Learning," New York: PrenticeHall.

Brand, S., Reimer, T. \& Opwis, K. (2007). "How Do We Learn in a Negative Mood? Effects of a Negative Mood on Learning's Transfer," Learning and Instruction, Vol. 17, Issue 1, 1-16.

Brown, R. G., Scott, L. C., Bench, C. J., \& Dolan, R. J. (1994). "Cognitive Function In Depression: It's Relationship to the Presence and Severity of Intellectual Decline," Psychological Medicine, 24, 829-847.

Bryan, T., Mathur, S. \& Sullivan, K. (1996). "The Impact of Positive Mood on Learning," Learning Disability Quarterly, Vol. 19, No. 3, 153-162.

Carver, C. S. \& Scheier, M. F. (1990). "Origins and Functions of Positive and Negative Affect: A Control Process View," Psychological Review, 97, 19-35.

Cervone, D., Kopp, D. A., Schaumann, L. \& Scott, W. D. (1994). "Mood, Self-efficacy, and Performance Standards: Lower Moods Induce Higher Standards of Performance," Journal of Personality and Social Psychology, 67, 499-512.

Chavez, C. I. \& Méndez, M. J. (2008). "Mood, Emotion, and Affect in Group Performance: An Experiential Exercise," Organization Management Journal, 5, 153-166.

Cianci, A. M. \& Bierstaker, J. L. (2009). 'The Impact of Positive and Negative Mood on the Hypothesis Generation and Ethical 
Judgments of Auditors,' Journal of Practice \& Theory, Vol. 28, No. 2, 119-144.

Côté, S. \& Miners, C. T. H. (2006). "Emotional Intelligence, Cognitive Intelligence, and Job Performance," Administrative Science Quarterly, Vol. 51, No. 1, 1-28.

Duncker, K. (1945). 'On Problem Solving,' Psychological Monographs, 58 (5, Whole No. 270).

Elerina M. D. T. (2008). 'The Effects of Job Satisfaction, Organizational Commitment, and Motivation on Local Government Managerial Performance,' Gadjah Mada University, Dissertation (unpublished).

Ellis, H. C. \& Ashbrook, P. W. (1988). 'Resource Allocation Model of the Effects of Depressed Mood States on Memory,' In K. Fiedler, \& J. Forgas (Eds.), Affects, cognition, and social behavior (pp. 25-43). Toronto: Hogrefe International.

Ellis, H. C., Thomas, R.L. \& Rodrigues, I.A. (1984)."Emotional Mood States and Memory: Elaborative Encoding, Semantic Processing, and Cognitive Effort," Journal of Experimental Psychology: Learning, Memory, and Cognition, 10, 470-482.

Erez, A. \& Isen, A. M. (2002). "The Influence of Positive Affect on the Components of Expectancy Motivation," Journal of Applied Psychology, 87(6), 1055-1067.

Estrada, C. A., Isen, A. M., \& Young, M. J. (1997). "Positive Affect Facilitates Integration of Information and Decreases Anchoring in Reasoning among Physicians," Organizational Behavior and Human Decision Processes, 72, 117-135.

Forest, D., Clark, M. S., Mills, J. \& Isen, A. M. (1979). "Helping as a Function of Feeling State and Nature of The Helping Behavior," Motivation and Emotion, 3(2), 161-169.

Fredrickson, B. L. \& Branigan, C. (2005). "Positive Emotions Broaden the Scope of
Attention and Thought-Action Repertoires," Cognition and Emotion, 19, 313-332.

Gendolla, G. H. E. \& Krusken, J. (2002). "The Joint Effect of Informational Mood Impact and Performance-Contingent Consequences on Effort-Related Cardiovascular Response," Journal of Personality and Social Psychology, 83, 271-283.

George, J. M. \& Jones, G. R. (1997). "Experiencing Work: Values, Attitudes, and Moods," Human Relations, Vol. 50, No. 4, 393.

Goleman, D. (1995). "Emotional Intelligence: Why It Can Matter More Than IQ," New York: Bantam Books.

Goleman, D., Boyatzis, R. \& McKee, A. (2002). Primal Leadership: Realizing the Power of Emotional Intelligence, Boston: Harvard Business School Press.

Goodhue, D. L. \& Thompson, R. L. (1995). "Task Technology Fit and Individual Performance," MIS Quarterly, 19 (2), 213236.

Greene, T. R. \& Noice, H. (1988). "Influence of Positive Affect upon Creative Thinking and Problem Solving in Children," Psychological Report, 63, 895-898.

Gujarati, D. N. (1995). Basic Econometrics, New York: McGraw-Hill.

Hanin, Y. L. (2000). Emotions in Sport, Champaign, IL: Human Kinetics.

Isen, A. M. (1984). 'Toward Understanding the Role of Affect in Cognition,' In R. S. Wyer, and T. K. Srull (Eds.), Handbook of social cognition, Vol. 3 (pp. 179-236). Hillsdale, NJ: Erlbaum.

Isen, A. M. (1987). 'The Influence of Positive and Negative Effect on Cognitive Organization,' In N.L. Stein, E. Leventhal, and T. Trabasso (Eds.), Psychological and Biological Approaches to Emotion (pp. 7594). Hillsdale, NJ: Lawrence Erlbaum. 
Isen, A. M., Daubman, K. A. \& Nowicki, G. P. (1987)."Positive Affect Facilitates Creative Problem Solving," Journal of Personality and Social Psychology, 56(6), 1122-1131.

Isen, A. M., Jhonson, M. M. S., Mertz, E. \& Robinson, G. F. (1985). "The Influence of Positive Affect on the Unusualness of Word Associations," Journal of Personality and Social Psychology, 48, 1413-1426.

Isen, A. M. \& Labroo, A. A. (2003). 'Some Ways in Which Positive Affect Facilitates Decision Making and Judgement,' In J. Shanteau, and S. L. Schneider (Eds.), Emerging perspectives on judgement and decision research (pp. 365-393). New York, NY: Cambridge University Press.

Isen, A. M. \& Patrick, R. (1983). "The Effect of Positive Feelings on Risk-Taking: When the Chips Are down," Organizational Behavior and Human Performance, 31, 194-202.

Isen, A. M. \& Reeve, J. (2005). "The Influence of Positive Affect on Intrinsic and Extrinsic Motivation: Facilitating Enjoyment of Play, Responsible Work Behavior, and SelfControl," Motivation and Emotion, 29, 4, 297325.

Isen, A. M., Rosenzweig, A. S. \& Young, M. J. (1991). "The Influence of Positive Affect on Clinical Problem Solving," Medical Decision Making, 11(3), 221-227.

Isen, A. M., Shalker, T. E., Clark, M. \& Karp, L. (1978). "Affect, Accessibility of Material in Memory, and Behavior: A Cognitive Loop?," Journal of Personality and Social Psychology, 36(1), 1-12.

Jaeger, D. A. \& Page, M. (1996). "Degrees Matter: New Evidence on Sheepskin Effects in the Returns to Education," Review of Economics and Statistics, 78(4), 733-740.

Jeon, J.-O. (1990). "An Empirical Investigation of the Relationship between Affective States, in-Store Browsing, and Impulse Buying," University of Alabama. Dissertation (unpublished).
Jones, G. R. \& George, J. M. (1998). "The Experience and Evolution of Trust: Implications for Cooperation and Teamwork," The Academy of Management Review, 23 (3), 531.

Kane, T. J. \& Rouse, C. E. (1995). "LaborMarket Returns to Two-and Four-Year College," American Economic Review, 85(3), 600-614.

Keller, P. A., Lipkus, I. M. \& Rimer, B. K. (2002). "Depressive Realism and Health Risk Accuracy: The Negative Consequences of Positive Mood," The Journal of Consumer Research, Vol. 29, No. 1, 57-69.

Lan, M. C. \& Li, M. (2003). 'The Relationship between Classroom Practices on Homework and Student Performance in Mathematics on TIMSS,' University of Washington.

Lane, A. M. \& Terry, P. C. (2000). "The Nature of Mood: Development of a Theoretical Model with a Focus on Depression," Journal of Applied Sport Psychology, 12, 16-33.

Lasso, R. A. (2008). 'Is our Students Learning? Using Assessments to Measure and Improve Law School Learning,' John Marshall Law School.

Lebcir, R. M., Wells, H. \& Bond, A. (2008). "Factors Affecting Academic Performance of International Students in Project Management Courses: A Case Study from a British Post 92 University," International Journal of Project Management, Vol. 26, Issue 3, 268-274.

Leight, K. A. \& Ellis, H. C. (1981). "Emotional Mood States, Strategies and StateDependency in Memory," Journal of Verbal Learning and Verbal Behavior, 20, 251-266. Magno, C. (2003). "Modern Trends in the Psychology of Learning and Teaching," UPHL Institutional Journal, Vol. 1, Issue 1, 12-31.

Martin, L. L. \& Tesser, A. (1996). "Some Ruminative Thoughts," In R.S. Wyer (Ed.), 
The handbook of social cognition (Vol. 9, pp. 1-48). Mahwah, NJ: Lawrence Erlbaum.

Mayer, J. D. \& Salovey, P. (1995). "Emotional Intelligence and the Construction and Regulation of Feelings," Applied and Preventive Psychology, 4.197-208.

Mednick, M. T., Mednick, S. A. \& Mednick, E. V. (1964). "Incubation of Creative Performance and Specific Associative Priming," Journal of Abnormal and Social Psychology, 69, 84-88.

Oaksford, M., Morris, F., Grainger, B., Mark, J. \& Williams, G. (1996). "Mood, Reasoning, and Central Executive Processes," Journal of Experimental Psychology: Learning, Memory, and Cognition, 22, 476-492.

Park, J. H. (2002). " The Effect of Product Presentation on Mood, Perceived Risk, and Apparel Purchase Intention in Internet Apparel Shopping," Ohio State University.

Parkinson, B., Totterdell, P., Briner, R. B. \& Reynolds, S. (1996). "Changing Moods: The Psychology of Mood and Mood Regulation," London: Longman.

Peck, S. R. (1994). "Exploring the Link between Organizational Strategy and the Employment Relationship: The Role of Human Resources Policy," Journal of Management Studies, 31, 715-735.

Pekrun, R. \& Jerusalem, M. (1996). 'Leistungsbezogenes Denken und Fuhlen: Eine Ubersicht zur psychologischen Forschung,' [Thinking and feeling for performance: an overview of psychological research]. In J. Moller, and 0. Kller (Eds.), Emotion, Kognition und Schulleistung [Emotion, cognition and performance at school] (pp. 3-22). Weinheim: Psychologie Verlags Union.

Petty, R. E., Schumann, D. W, Richman, S. A. \& Strathman A. J. (1993). "Positive Mood and Persuasion: Different Roles for Affect under High- And Low-Elaboration Conditions,"
Journal of Personality and Social Psychology, 64(1), 5-20.

Prajogo, W. (2008). 'The Effects of Leadership and Personality on Capital Social and Its Impact on Performance,' Gadjah Mada University, Dissertation (unpublished).

Ramsden, P. (1999). 'Learning to Teach in Higher Education,' New York: Routledge.

Reyes, F. (2000). 'Engineering the Curriculum: A Guidebook to Educators and School Managers,' De la Salle University: DLSU Press Inc.

Salovey. P. \& Grewal. D. (2005). The Science of Emotional Intelligence, Current Directions in Psychological Science, Emotional Intelligence from Wikipedia, the Free Encyclopedia.

Schwarz, N. (2001). "Feelings as Information: Implications for Affective Influences on Information Processing," In Martin, L. L., \& Clore, G. L. (Eds.), Theories of mood and cognition, (pp 159-176). Mahwah, NJ: Lawrence Erlbaum.

Schwarz, N. \& Bless, H. (1991). "Happy and Mindless, but Sad and Smart? The Impact of Affective States on Analytic Reasoning," In P. Forgas (Ed.), Emotion and Social Judgement (pp. 55-71). Oxford: Pergamon.

Spielberger, C. D. (1991). 'Manual for the State-Trait Anger Expression Inventory,' Odessa, FL: Psychological Assessment Resources.

Swinyard, W. R. (1993). "The Effect of Mood, Involvement, and Quality of Store Experience on Shopping Intention," The Journal of Consumer Research, Vol. 20, No. 2, pp. 271280.

Tabachnick, B. G. \& Fidell, L. S. (1996). "Using Multivariate Statistics," Harper Collins College Publishers. 
15 Journal of e-Learning and Higher Education

Trzepacz, P. T. \& Baker R. W. (1993). The Psychiatric Mental Status Examination, Oxford, U.K.: Oxford University Press. p. 202.

Tsai, W.-C., Chen, H.-W. \& Cheng, J.-W. (2009). Employee Positive Moods As a Mediator Linking Transformational Leadership and Employee Work Outcomes," The International Journal of Human Resource Management, Vol. 20, No. 1, 206-219.

Watson, D. \& Tellegen A. (1985). "Toward a Consensual Structure of Mood," Psychological Bulletin, 98, 219-235.

Weiss, H. M., Nicholas, J. P. \& Daus, C.S. (1999). "An Examination of the Joint Effects of Affective Experiences and Job Beliefs on Job Satisfaction and Variations in Affective Experiences over Time," Organizational Behavior and Human Decision Processes, 78(1), 1-24.

Wicklund, R. A. (1979). "The Influence of SelfAwareness on Human Behavior," American Scientist, 67, 187-193. 